\title{
Macrophage imbalance (M1 vs. M2) and upregulation of mast cells in wall of ruptured human cerebral aneurysms: preliminary results
}

\author{
David Hasan ${ }^{1,4^{*}}$, Nohra Chalouhi ${ }^{2}$, Pascal Jabbour ${ }^{2}$ and Tomoki Hashimoto ${ }^{3}$
}

\begin{abstract}
Background: $\mathrm{M} 1$ and $\mathrm{M} 2$ cells are two major subsets of human macrophages that exert opposite effects on the inflammatory response. This study aims to investigate the role of macrophage M1/M2 imbalance and mast cells in the progression of human cerebral aneurysms to rupture.

Methods: Ten patients with cerebral aneurysms (five ruptured and five unruptured) underwent microsurgical clipping. During the procedure, a segment of the aneurysm dome was resected and immunostained with monoclonal antibodies for M1 cells (anti-HLA DR), M2 cells (anti-CD 163), and mast cells (anti-tryptase clone AA). A segment of the superficial temporal artery (STA) was also removed and immunostained with monoclonal antibodies for M1, M2, and mast cells.

Results: All ten aneurysm tissues stained positive for M1, M2, and mast cells. M1 and M2 cells were present in equal proportions in unruptured aneurysms. This contrasted with a marked predominance of M1 over M2 cells in ruptured aneurysms $(p=0.045)$. Mast cells were also prominently upregulated in ruptured aneurysms $(p=0.001)$. Few M1 and M2 cells were present in STA samples.

Conclusions: M1/M2 macrophages and mast cells are found in human cerebral aneurysms; however, M1 and mast cell expression seems to markedly increase in ruptured aneurysms. These findings suggest that macrophage M1/M2 imbalance and upregulation of mast cells may have a role in the progression of cerebral aneurysms to rupture.
\end{abstract}

Keywords: Aneurysm, Inflammation, Macrophages, M1, M2, Mast cells

\section{Background}

Monocytes originate from bone marrow-derived progenitor cells and do not proliferate in the blood [1-4]. Mononuclear phagocytes develop into morphologically and functionally distinct cell types in response to the tissue microenvironment (e.g., lung alveolar macrophages, Kupffer cells, decidual macrophages) [5,6]. Two major subsets of human macrophages can be defined in atherosclerotic plaques: $\mathrm{CD} 14^{\text {high }} \mathrm{CD} 16^{\text {low }}$ macrophages, which typically represent $85 \%$ to $95 \%$ of monocytes, and $\mathrm{CD} 14^{\text {low }} \mathrm{CD} 16^{\text {high }}$ macrophages, which account for the remaining 5 to $15 \%[2-4,7]$. These macrophages play

\footnotetext{
* Correspondence: david-hasan@uiowa.edu

${ }^{1}$ Department of Neurosurgery, Carver College of Medicine, University of lowa, lowa City, IA, USA

${ }^{4}$ Department of Neurosurgery, University of lowa Hospitals and Clinics, 200

Hawkins Drive, JCP 1616, lowa City, IA 52242, USA

Full list of author information is available at the end of the article
}

opposite roles in inflammation [2-4,7]. A growing body of evidence suggests that a polarized macrophage population can contribute to systemic and neuroinflammatory diseases $[8,9]$.

Macrophages play a critical role in cerebral aneurysm formation and rupture [10-13]. Macrophage depletion and knockout of monocyte chemotactic protein-1 gene in mice reduce the incidence cerebral aneurysm formation [13]. Recent studies also have revealed that mast cells contribute to various vascular diseases through degranulation and release of cytokines including cerebral aneurysm formation $[14,15]$.

We hypothesize that macrophage imbalance and upregulation of mast cells are more pronounced in ruptured compared to unruptured human cerebral aneurysms. The goal of this study is to provide immunohistological evidence of this hypothesis. 


\section{Material and methods}

The study was approved by the University of Iowa Institutional Review Board (IRB). Ten consecutive patients with cerebral aneurysms who underwent microsurgical clipping during a 6-month interval were identified. No patients were excluded, except those who were treated with endovascular means. Five patients with unruptured aneurysms and five patients with ruptured aneurysms were included in the study. Mean age was 55 years (range 44-67 years) (Table 1). Informed consent was obtained in all patients prior to microsurgical clipping. A segment of the aneurysm dome $(\geq 1 \mathrm{~mm})$ and the superficial temporal artery (STA) $(\geq 2 \mathrm{~mm})$ was removed from each patient and placed in formalin. All 20 specimens (10 aneurysms and 10 STAs) were immunostained with monoclonal antibodies to mast cells using anti-mast cells tryptase clone AA1 (DakoCytomation, Carpentaria, CA), M1 cells using anti-HLA DR (ABCAM, Cambridge MA), and M2 cells using anti-CD 163 (ABCAM, Cambridge MA).

The entire tissue sample collected from the aneurysm dome was embedded in paraffin and analyzed. The sample size, however, differed from one patient to another based on the size of the aneurysm and ease of tissue collection following successful clipping. All fields were analyzed per sample and, for consistency, we chose the field with the highest concentration of cells for semiquantitative analysis. Each field covered the entire section of the aneurysm tissue and included all layers of the wall of the aneurysm dome.

Semiquantitative analysis of the slides was performed based on cell count (immunostained positive cells) per high-power field $(\mathrm{HPF})(40 \times)$ : grade $0=0-10$ cells per $\mathrm{HPF}$, grade $1=10-20$ cells per $\mathrm{HPF}$, grade $2=20-30$ cells per HPF, and grade $3 \geq 30$ cells per HPF. All specimens were assessed by an observer who was blinded to the clinical data and source of tissue.

Statistical analysis was performed using the KruskalWallis test, a nonparametric ANOVA test. This test is used for comparing more than two samples that are independent, or not related. The parametric equivalence of the Kruskal-Wallis test is the one-way analysis of variance (ANOVA). The factual null hypothesis is that the populations from which the samples originate have the same median. When the Kruskal-Wallis test leads to significant results, then at least one of the samples is different from the other samples. The test does not identify where the differences occur or how many differences actually occur.

\section{Results}

Ten patients with ten aneurysms were included in this study. All ten aneurysms stained positive for expression of M1, M2, and mast cells using anti-HLA DR, anti-CD 163 , and anti-mast cells tryptase clone AA1 monoclonal antibodies (Figures 1 and 2).

Table 1 Patient and aneurysm characteristics

\begin{tabular}{|c|c|c|c|c|c|c|c|c|}
\hline Patient no. & Age & Sex & Aneurysm location & Aneurysm size (mm) & $\begin{array}{c}\text { Rupture } \\
\text { (SAH) }\end{array}$ & $\begin{array}{c}\text { M1 } \\
\text { A/STA }\end{array}$ & $\begin{array}{c}\text { M2 } \\
\text { A/STA }\end{array}$ & $\begin{array}{c}\text { Mast } \\
\text { cells }\end{array}$ \\
\hline 1 & 50 & $\mathrm{~F}$ & L-ICA & $9 \times 6$ & No & $\begin{array}{c}1 / 0 \\
(13 / 4)\end{array}$ & $\begin{array}{c}1 / 0 \\
(11 / 5)\end{array}$ & $\begin{array}{c}1 \\
(4)\end{array}$ \\
\hline 2 & 56 & M & R-MCA & $5 \times 4$ & No & $\begin{array}{c}1 / 0 \\
(15 / 7)\end{array}$ & $\begin{array}{c}1 / 0 \\
(11 / 4)\end{array}$ & $\begin{array}{c}1 \\
(7)\end{array}$ \\
\hline 3 & 52 & $\mathrm{~F}$ & L-MCA & $10 \times 10$ & No & $\begin{array}{c}2 / 0 \\
(27 / 3)\end{array}$ & $\begin{array}{c}1 / 0 \\
(18 / 6)\end{array}$ & $\begin{array}{c}1 \\
(5)\end{array}$ \\
\hline 4 & 67 & $F$ & R-MCA & $7 \times 8$ & No & $\begin{array}{c}2 / 0 \\
(26 / 5) \\
\end{array}$ & $\begin{array}{c}2 / 0 \\
(27 / 4)\end{array}$ & $\begin{array}{r}1 \\
(3) \\
\end{array}$ \\
\hline 5 & 47 & M & R-Pcomm & $14 \times 11$ & No & $\begin{array}{c}2 / 0 \\
(28 / 7)\end{array}$ & $\begin{array}{c}2 / 0 \\
(27 / 5)\end{array}$ & $\begin{array}{c}1 \\
(5) \\
\end{array}$ \\
\hline 6 & 68 & M & L-MCA & $12 \times 9$ & Yes & $\begin{array}{c}3 / 0 \\
(39 / 6)\end{array}$ & $\begin{array}{c}1 / 0 \\
(12 / 3)\end{array}$ & $\begin{array}{c}3 \\
(41)\end{array}$ \\
\hline 7 & 44 & M & R-MCA & $6 \times 5$ & Yes & $\begin{array}{c}3 / 1 \\
(41 / 2)\end{array}$ & $\begin{array}{c}2 / 1 \\
(22 / 4)\end{array}$ & $\begin{array}{c}3 \\
(39)\end{array}$ \\
\hline 8 & 38 & $F$ & A-comm & $8 \times 8$ & Yes & $\begin{array}{c}3 / 0 \\
(37 / 3)\end{array}$ & $\begin{array}{c}1 / 0 \\
(14 / 7)\end{array}$ & $\begin{array}{c}3 \\
(31) \\
\end{array}$ \\
\hline 9 & 55 & $\mathrm{~F}$ & L-MCA & $9 \times 10$ & Yes & $\begin{array}{c}3 / 0 \\
(44 / 6) \\
\end{array}$ & $\begin{array}{c}1 / 0 \\
(13 / 4) \\
\end{array}$ & $\begin{array}{c}3 \\
(49) \\
\end{array}$ \\
\hline 10 & 74 & $M$ & R-PICA & $14 \times 15$ & Yes & $\begin{array}{c}3 / 0 \\
(38 / 4)\end{array}$ & $\begin{array}{c}1 / 0 \\
(15 / 6)\end{array}$ & $\begin{array}{c}3 \\
(34)\end{array}$ \\
\hline
\end{tabular}

$\mathrm{F}=$ female; $\mathrm{M}=$ male; $\mathrm{L}=$ left; $\mathrm{R}=$ right; $\mathrm{ICA}=$ internal carotid artery; $\mathrm{MCA}=$ middle cerebral artery; $\mathrm{A}$-Comm = anterior communicating artery; Pcomm = posterior communicating artery; PICA = posterior communicating artery; $\mathrm{A} / \mathrm{STA}=$ aneurysm/superficial temporal artery; grade $0=0-10$ cells per HPF, grade $1=10-20$ cells per HPF, grade $2=20-30$ cells per HPF, and grade $3 \geq 30$ cells per HPF. Numbers in parentheses are absolute cell counts. 


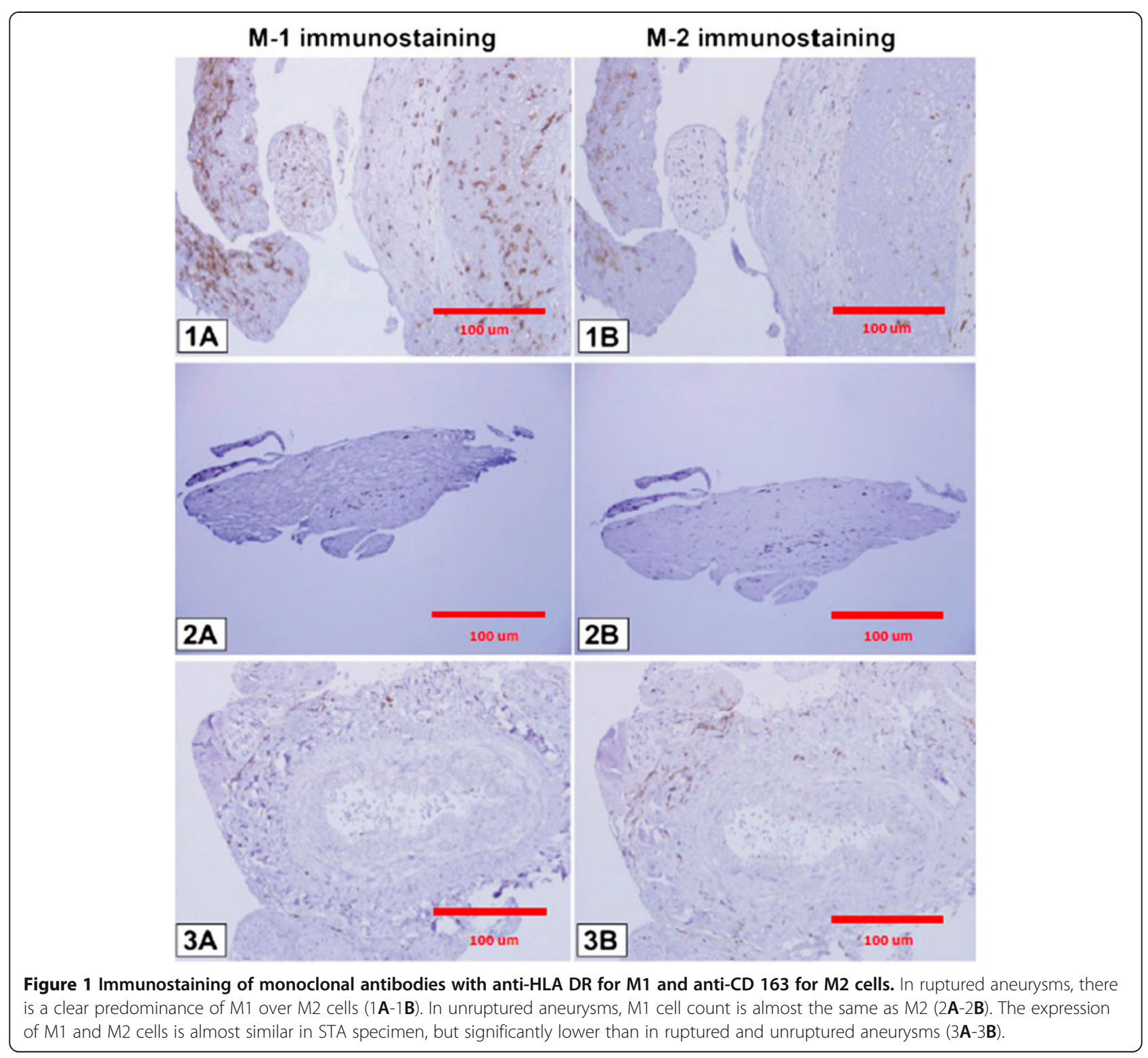

\section{Mast cells}

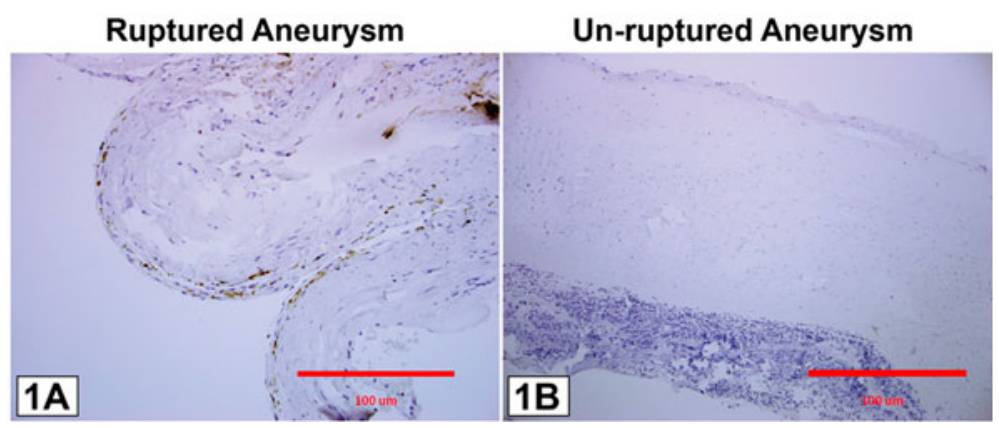

Figure 2 Immunostaining of monoclonal antibodies for anti-mast cells tryptase (clone AA1). There are more mast cells visible in ruptured aneurysms than in unruptured aneurysms. 


\section{Macrophages}

Unruptured aneurysms stained almost equally for M1 and M2 cells. Ruptured cerebral aneurysms, however, stained more abundantly with anti-HLA DR monoclonal antibodies, indicating a predominance of M1 over M2 cells. There was only scant staining of M1 and M2 cells in the ten samples of STA tissue (Figure 1).

\section{Mast cells}

Unruptured aneurysms had few mast cells. Ruptured aneurysms had prominently more mast cells stained with monoclonal antibody for anti-mast cells tryptase clone AA1 compared with unruptured aneurysms. There was abundant mast cell staining in STA tissue but this was limited to adventitia and did not extend to the other layers, namely the media, intima, and subendothelium (Figure 2).

\section{Statistical analysis}

Areas immunostained for M1 and M2 cells with cell count differences were localized, and semiquantitative analysis was performed (Figure 3). M1 cell expression was significantly higher than M2 cell expression $(p=0.045)$ in ruptured aneurysms. M1 cell expression was also greater $(p=0.001)$ in ruptured and unruptured aneurysms vs. STA. Mast cell expression was significantly higher in ruptured aneurysms vs. unruptured aneurysms $(p=0.001)$.

\section{Discussion}

\section{Monocyte differentiation into M1 and M2 subsets}

Monocytes differentiate into heterogeneous cells $[1-4,16]$. Differential expression of selected surface molecules is used to identify monocyte subsets in humans and mice. In humans, there are two distinct subsets of macrophages based on the expression of CD16 [7]. CD14 $4^{\text {high }} / \mathrm{CD} 16^{\text {low }}$ cells are the primary subtype of macrophages as they represent $80 \%$ to $90 \%$ of circulating monocytes and express high levels of the chemokine receptor CCR2 and low levels of CX3CR1. They are poor producers of inflammatory cytokines but release interleukin (IL) 1, IL 13, IL 14, IL 4, IL-10, transforming growth factor- $\beta$ (TGF- $\beta$ ), and vitamin D. Conversely, CD $14^{\text {low }} / \mathrm{CD} 16^{\text {high }}$ monocytes have a CX3CR $1^{\text {high }} / \mathrm{CCR} 2^{\text {low }}$ phenotype and account for inflammatory mediator production, including tumor necrosis factor- $\alpha$ (TNF- $\alpha$ ), IL 1, IL 6, IL 12, IL 23, matrix metalloproteinases (MMP), prostaglandins, and leukotrienes $[1-4,7]$. In mice, monocytes differentiate into two major types of macrophages (M1 and M2) $[1-4,6,17,18]$. M1 and M2 macrophages play opposite roles during inflammation, although both are present in atherosclerotic lesions. M1 macrophages are differentiated from Ly6 $\mathrm{C}^{\text {high }}$ monocytes. They promote inflammation by producing high levels of IL-2, IL-23, IL-6, IL-1, and TNF- $\alpha$. M2

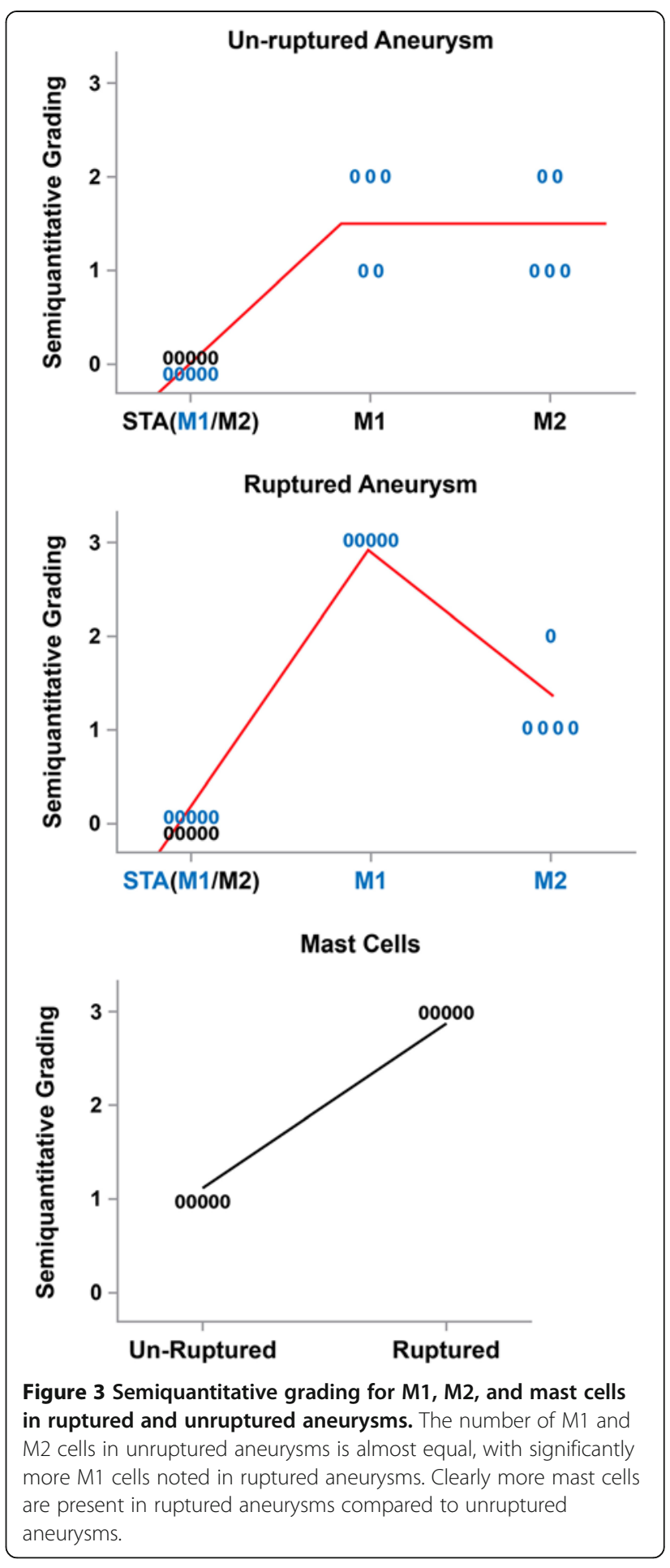

macrophages, on the other hand, are differentiated from Ly6C ${ }^{\text {low }}$ monocytes. They differentiate in the presence of IL-4, IL-13, IL-1, or vitamin D3, tend to produce a large amount of IL-10, and express scavenger receptors, mannose receptors, and arginase [1-5]. Unlike M1 macrophages, these cells promote resolution of inflammation. 


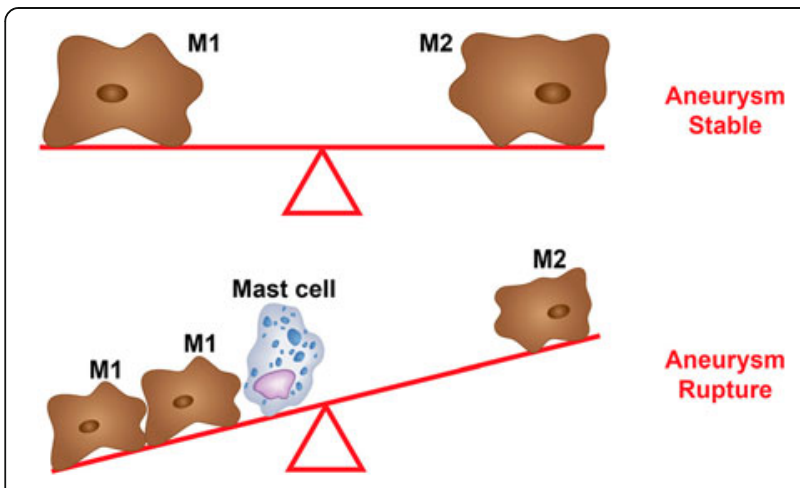

Figure 4 M1 vs. M2 balance. Schematic diagram illustrating our hypothesis that a balance between M1 and $\mathrm{M} 2$ cells leads to stable aneurysm and that imbalance between $M 1$ and $M 2$ cells with increased population of $\mathrm{M} 1$ cells and upregulation of mast cells predisposes the aneurysm to rupture.

Recently, there has been a great deal of interest in macrophage heterogeneity in atherosclerotic lesions, particularly regarding the roles of M1 versus M2 macrophages. There is also evidence that an imbalance in the ratio of M1 to M2 macrophages in advanced atherosclerosis impairs resolution of inflammation in vitro [1-5].

\section{Macrophages and cerebral aneurysms}

Macrophage-depleted and monocyte chemotactic protein-1 knockout mice have a reduced incidence of cerebral aneurysms [13]. Macrophages were observed in the wall of hypertension-induced cerebral aneurysms in rats and were reported to secrete extracellular matrix-degrading proteolytic enzymes and induce apoptosis of smooth muscle cells [12]. Additionally, macrophages induce fibrosis through secretion of TGF- $\beta$ and promote the release of reactive oxygen species, TNF- $\alpha$ and IL-1 [10]. Macrophages are also an important source of MMP 2 and 9, which presumably contribute to the reduction of mechanical strength and rupture of aneurysms. MMP-2 is expressed in most cerebral aneurysms, whereas MMP-9 is expressed primarily in aneurysms with atherosclerotic changes $[19,20]$. Macrophages are an especially important source of growth factors and cytokines that stimulate fibrosis [3].

Platelet-derived growth factor, basic fibroblast growth factor (bFGF), and transforming growth factors alpha (TGF- $\alpha$ ) and beta are expressed by immunohistochemistry in intracranial aneurysms [20-23]. Transcription of procollagens I and III is promoted by TGF- $\beta$, secreted in large part by macrophages [24]. In aneurysms, the progression of smooth muscle cells from a contractile to a synthetic phenotype and the increase in relative numbers of smooth muscle cells (by increased proliferation of smooth muscle cells and myointimal hyperplasia) may compensate for the increased MMP expression and sustain aneurysm wall strength [25]. In concordance with this theory, the aneurysm wall shows, by in situ hybridization,

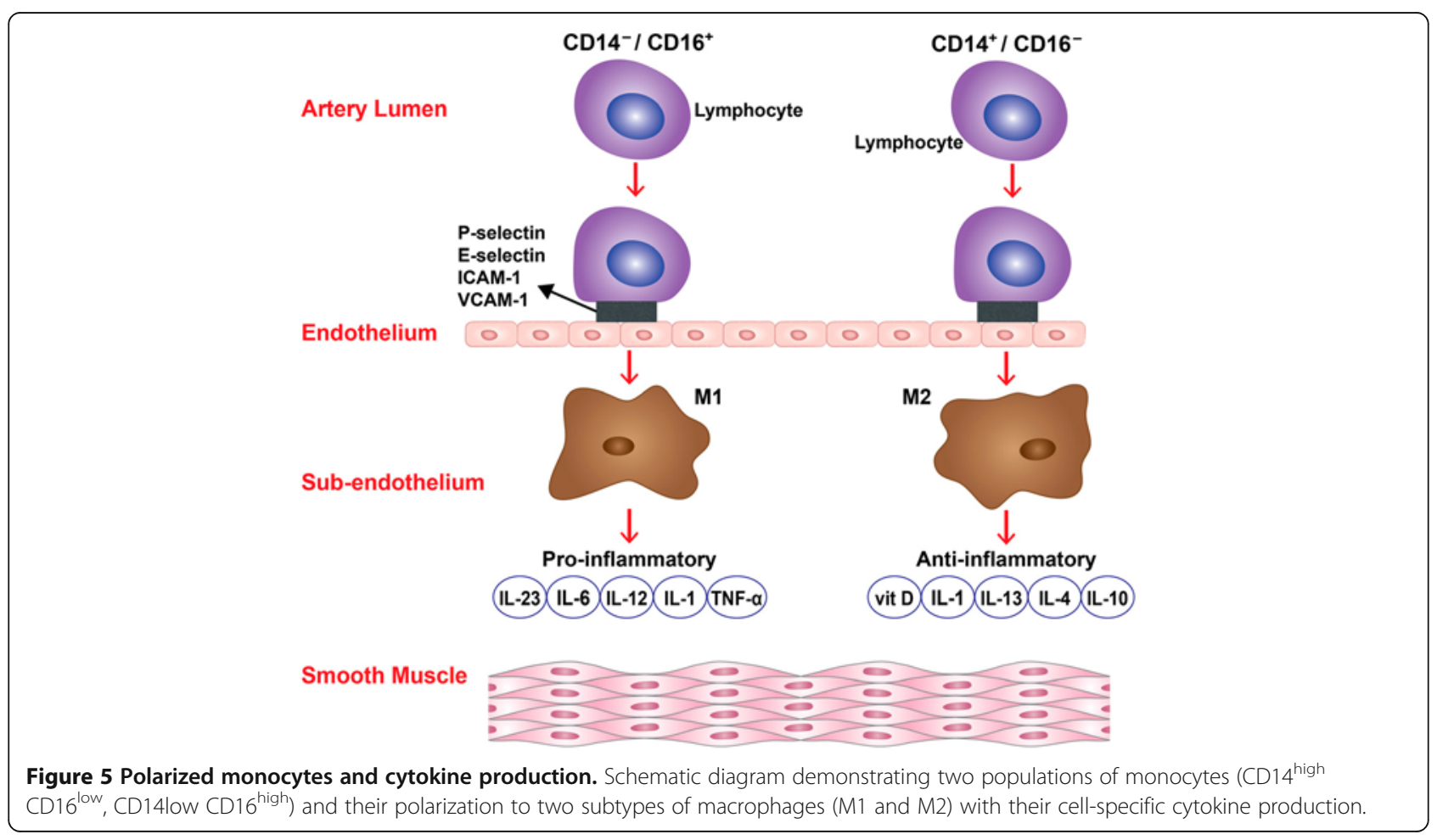


increased synthesis of collagen type III but a slight diminution in expression of collagen type III in immunostaining, probably indicating faster collagen turnover. Mural cells die during aneurysm progression and the extracellular matrix-synthesizing capability is progressively lost, leading to a decrease in tensile wall strength and an increase in susceptibility of the aneurysm to rupture [25].

Based on the classification of atherosclerosis by histological changes, nearly all cerebral aneurysms can be considered atherosclerotic [26]. Features of advanced atherosclerosis (including a core of atheromatous debris, a fibrous cap with macrophages and T-cells) are observed in approximately half of intracranial aneurysms [11,26], and myointimal hyperplasia occurs in the other half [25]. Thrombosis occurs in some cerebral aneurysms, which further amplifies the ongoing inflammatory reaction and wall degeneration, with loss of tensile strength and ultimately aneurysm rupture [24,27-32].

\section{Mast cells and cerebral aneurysms}

Ishibashi et al. [14] examined the role of mast cells in the formation of cerebral aneurysms in an experimental rat model. They found that the number of mast cells was significantly increased in aneurysm walls. They also showed that using mast cell degranulation inhibitors attenuated the chronic inflammatory process in the aneurysm wall. This was evident from the decreased nuclear factor-kappa B activation, macrophage infiltration, and expression of monocyte chemoattractant protein-1, MMP, and interleukin-1beta. They also demonstrated that the degranulation of mast cells led to increased expression and activation of MMP-2 and -9 and induced nitric oxide synthase in cultured smooth muscle cells from rat intracranial arteries. Their results suggest that mast cells play a critical role in aneurysm formation in rats through the induction of inflammation. However, they did not address the question of whether mast cells contribute to the progression of cerebral aneurysms to rupture and whether these cells are present in human cerebral aneurysm tissue.

\section{Interpretation of current findings}

We found that M1 and M2 cells were present in equal proportions in unruptured aneurysms with very few mast cells, which suggests that the pro- and antiinflammatory activities of M1 and M2 cells, respectively, may be well balanced in the walls of unruptured aneurysms (Figure 4). However, ruptured aneurysms appear to lose this critical M1/M2 balance, as M1 cell expression was significantly more pronounced than M2 cell expression in ruptured aneurysm walls. Additionally, mast cells were found to be significantly upregulated in ruptured cerebral aneurysm tissue. Collectively, these data suggest

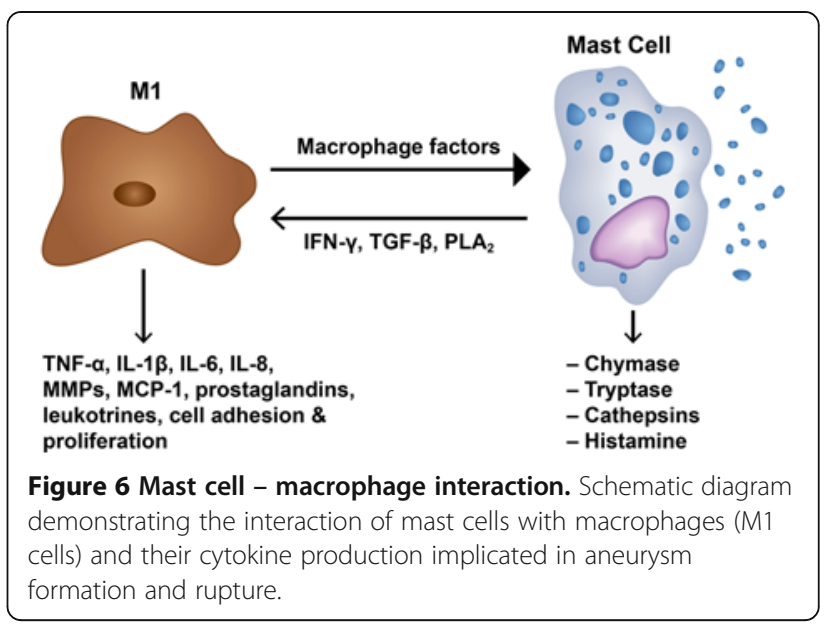

that a polarized proinflammatory response involving M1 macrophages and mast cells may have a role in the cascade of events leading to aneurysm rupture (Figures 5 and 6). However, the relationship between macrophage subsets and mast cells remains to be defined.

\section{Limitations}

This study is limited by the small sample size, and generalization of the results may not be appropriate. It also is difficult to determine whether increased expression of M1 vs. M2 and upregulation of mast cells in ruptured cerebral aneurysms (compared to non-ruptured) is due to inflammation that occurs following the rupture of the aneurysm or whether there was an increase in expression of these molecules that preceded and led to rupture of the aneurysm.

\section{Conclusion}

M1, M2, and mast cells are expressed in the walls of human cerebral aneurysms. However, M1 and mast cell expression may increase significantly in ruptured aneurysms. Our findings suggest that macrophage M1/M2 imbalance and upregulation of mast cells may play a role in the progression of cerebral aneurysms to rupture. Mast cell activation and M1/M2 macrophage phenotypic modulation may represent important targets for future therapy.

\section{Abbreviations}

STA: Superficial temporal artery; HPF: High-power field; IL: Interleukin; TGF$\beta$ : Transforming growth factor- $\beta$; TNF- $\alpha$ : Tumor necrosis factor- $\alpha$; MMP: Matrix metalloproteinases; TGF- $\alpha$ : Transforming growth factor alpha.

\section{Competing interests}

The authors declare that they have no competing interest.

\section{Authors' contributions}

$\mathrm{DH}$ performed all surgical procedures; conceived and designed the study; acquired, analyzed, and interpreted the data; and drafted the manuscript. NC helped in data analysis and interpretation and helped drafting the manuscript. PJ and TH helped design the study, analyzed and interpreted 
the data. All authors have revised the manuscript critically for important intellectual content and have given final approval of the version to be published.

\section{Sources of funding}

This study was supported by NIH grant no. R03NS07922 to DH.

\section{Acknowledgments}

None

\section{Author details}

'Department of Neurosurgery, Carver College of Medicine, University of lowa, lowa City, IA, USA. Department of Neurosurgery, Thomas Jefferson University and Jefferson Hospital for Neuroscience, Philadelphia, PA, USA. ${ }^{3}$ Department of Anesthesia and Perioperative Care, University of California San Francisco, San Francisco, CA, USA. ${ }^{4}$ Department of Neurosurgery, University of lowa Hospitals and Clinics, 200 Hawkins Drive, JCP 1616, lowa City, IA 52242, USA.

Received: 17 July 2012 Accepted: 12 September 2012 Published: 21 September 2012

\section{References}

1. Geissmann F, Jung S, Littman DR: Blood monocytes consist of two principal subsets with distinct migratory properties. Immunity 2003, 19:71-82.

2. Gui T, Shimokado A, Sun Y, Akasaka T, Muragaki Y: Diverse roles of macrophages in atherosclerosis: from inflammatory biology to biomarker discovery. Mediators Inflamm 2012, 2012:693083.

3. Mantovani A, Garlanda C, Locati M: Macrophage diversity and polarization in atherosclerosis: a question of balance. Arterioscler Thromb Vasc Biol 2009, 29:1419-1423.

4. Sica A, Mantovani A: Macrophage plasticity and polarization: in vivo veritas. J Clin Invest 2012, 122:787-795.

5. Mantovani A, Sica A, Locati M: Macrophage polarization comes of age. Immunity 2005, 23:344-346.

6. Mantovani A, Sozzani S, Locati M, Allavena P, Sica A: Macrophage polarization: tumor-associated macrophages as a paradigm for polarized M2 mononuclear phagocytes. Trends Immunol 2002, 23:549-555.

7. Passlick B, Flieger D, Ziegler-Heitbrock HW: Identification and characterization of a novel monocyte subpopulation in human peripheral blood. Blood 1989, 74:2527-2534

8. Kigerl KA, Gensel JC, Ankeny DP, Alexander JK, Donnelly DJ, Popovich PG: Identification of two distinct macrophage subsets with divergent effects causing either neurotoxicity or regeneration in the injured mouse spinal cord. J Neurosci 2009, 29:13435-13444.

9. Gordon S: Macrophage heterogeneity and tissue lipids. J Clin Invest 2007 117:89-93.

10. Boyle JJ: Macrophage activation in atherosclerosis: pathogenesis and pharmacology of plaque rupture. Curr Vasc Pharmacol 2005, 3:63-68.

11. Chalouhi N, Ali MS, Jabbour PM, Tjoumakaris SI, Gonzalez LF, Rosenwasser $\mathrm{RH}$, Koch WJ, Dumont AS: Biology of intracranial aneurysms: role of inflammation. J Cereb Blood Flow Metab 2012, 32:1659-1676.

12. Jamous MA, Nagahiro S, Kitazato KT, Tamura T, Aziz HA, Shono M, Satoh K: Endothelial injury and inflammatory response induced by hemodynamic changes preceding intracranial aneurysm formation: experimental study in rats. J Neurosurg 2007, 107:405-411.

13. Kanematsu Y, Kanematsu M, Kurihara C, Tada Y, Tsou TL, van Rooijen N, Lawton MT, Young WL, Liang El, Nuki Y, Hashimoto T: Critical roles of macrophages in the formation of intracranial aneurysm. Stroke 2011, 42:173-178

14. Ishibashi R, Aoki T, Nishimura M, Hashimoto N, Miyamoto S: Contribution of mast cells to cerebral aneurysm formation. Curr Neurovasc Res 2010, 7:113-124.

15. Xu JM, Shi GP: Emerging role of mast cells and macrophages in cardiovascular and metabolic diseases. Endocr Rev 2012, 33:71-108.

16. Auffray C, Sieweke MH, Geissmann F: Blood monocytes: development, heterogeneity, and relationship with dendritic cells. Annu Rev Immunol 2009, 27:669-692.

17. Johnson JL, Newby AC: Macrophage heterogeneity in atherosclerotic plaques. Curr Opin Lipidol 2009, 20:370-378.
18. Paulson KE, Zhu SN, Chen M, Nurmohamed S, Jongstra-Bilen J, Cybulsky MI: Resident intimal dendritic cells accumulate lipid and contribute to the initiation of atherosclerosis. Circ Res 2010, 106:383-390.

19. Bruno G, Todor R, Lewis I, Chyatte D: Vascular extracellular matrix remodeling in cerebral aneurysms. J Neurosurg 1998, 89:431-440.

20. Caird J, Napoli C, Taggart C, Farrell M, Bouchier-Hayes D: Matrix metalloproteinases 2 and 9 in human atherosclerotic and nonatherosclerotic cerebral aneurysms. Eur J Neurol 2006, 13:1098-1105.

21. Kilic T, Sohrabifar M, Kurtkaya O, Yildirim O, Elmaci I, Gunel M, Pamir MN: Expression of structural proteins and angiogenic factors in normal arterial and unruptured and ruptured aneurysm walls. Neurosurgery 2005, 57:997-1007. discussion 1997-1007.

22. Krischek B, Kasuya H, Tajima A, Akagawa H, Sasaki T, Yoneyama T, Ujiie H, Kubo O, Bonin M, Takakura K, et al: Network-based gene expression analysis of intracranial aneurysm tissue reveals role of antigen presenting cells. Neuroscience 2008, 154:1398-1407.

23. Shi C, Awad IA, Jafari N, Lin S, Du P, Hage ZA, Shenkar R, Getch CC, Bredel $\mathrm{M}$, Batjer $\mathrm{HH}$, Bendok BR: Genomics of human intracranial aneurysm wall. Stroke 2009, 40:1252-1261.

24. Wynn TA: Cellular and molecular mechanisms of fibrosis. J Pathol 2008, 214:199-210.

25. Mimata C, Kitaoka M, Nagahiro S, lyama K, Hori H, Yoshioka H, Ushio Y: Differential distribution and expressions of collagens in the cerebral aneurysmal wall. Acta Neuropathol 1997, 94:197-206.

26. Kosierkiewicz TA, Factor SM, Dickson DW: Immunocytochemical studies of atherosclerotic lesions of cerebral berry aneurysms. J Neuropathol Exp Neurol 1994, 53:399-406.

27. Fontaine $\mathrm{V}$, Jacob MP, Houard X, Rossignol P, Plissonnier D, Angles-Cano E, Michel JB: Involvement of the mural thrombus as a site of protease release and activation in human aortic aneurysms. Am J Pathol 2002, 161:1701-1710.

28. Fontaine V, Touat Z, Mtairag el M, Vranckx R, Louedec L, Houard X, Andreassian B, Sebbag U, Palombi T, Jacob MP, et al: Role of leukocyte elastase in preventing cellular re-colonization of the mural thrombus. Am J Pathol 2004, 164:2077-2087.

29. Frosen J, Marjamaa J, Myllarniemi M, Abo-Ramadan U, Tulamo R, Niemela M, Hernesniemi J, Jaaskelainen J: Contribution of mural and bone marrowderived neointimal cells to thrombus organization and wall remodeling in a microsurgical murine saccular aneurysm model. Neurosurgery 2006, 58:936-944. discussion 936-944.

30. Frosen J, Piippo A, Paetau A, Kangasniemi M, Niemela M, Hernesniemi J, Jaaskelainen J: Remodeling of saccular cerebral artery aneurysm wall is associated with rupture: histological analysis of 24 unruptured and 42 ruptured cases. Stroke 2004, 35:2287-2293.

31. Peterson JW, Kwun BD, Teramura A, Hackett JD, Morgan JA, Nishizawa S, Bun T, Zervas NT: Immunological reaction against the aging human subarachnoid erythrocyte. A model for the onset of cerebral vasospasm after subarachnoid hemorrhage. J Neurosurg 1989, 71:718-726.

32. Wohner N: Role of cellular elements in thrombus formation and dissolution. Cardiovasc Hematol Agents Med Chem 2008, 6:224-228.

\section{doi:10.1186/1742-2094-9-222}

Cite this article as: Hasan et al:: Macrophage imbalance (M1 vs. M2) and upregulation of mast cells in wall of ruptured human cerebral aneurysms: preliminary results. Journal of Neuroinflammation 2012 9:222.

\section{Submit your next manuscript to BioMed Central and take full advantage of:}

- Convenient online submission

- Thorough peer review

- No space constraints or color figure charges

- Immediate publication on acceptance

- Inclusion in PubMed, CAS, Scopus and Google Scholar

- Research which is freely available for redistribution 